\title{
PLEADING GUILTY: A CRITIQUE OF FOUR MODELS*
}

\author{
H. RICHARD UVILLER $†$
}

\section{INTRODUCTION}

Negotiated settlement of a cause in litigation is no stranger to prevailing American notions of justice. Yet there is something less than fully gratifying about compromise, and when the high principles and great social purposes of criminal justice are set in the balance, the process sometimes seems downright unsavory. What has become of the guilty plea? Is it no longer the commendable gesture of contrition, the honest confession and open acceptance of responsibility? Is it not the first motion of the penitent, a recognition of the social ethic bespeaking a potential for redemption? Do we now consider the crafty, adversary courtroom battle a nobler course?

Somehow the once pure and salubrious guilty plea has become inextricably associated with "plea bargaining," that baleful term connoting commercial exchange of advantage more appropriate to a Moroccan market than the halls of justice. Disposition without trial can no longer be regarded as a forthright concession coupled with a blind supplication for mercy. Courtroom realities, new or newly perceived, have engendered a more modern (read: cynical) appreciation of the transaction. In many jurisdictions, criminal defendants have learned that their accusation awards them a marketable service: the exclusive power to save the state the time, effort, and risk entailed in the trial of the accusation. Well employed, particularly in a stressed market, the decision of a defendant to forego trial may be traded for substantial benefits in mitigating the full force of the law's formal demand for judgment and punishment. The result of this sort of economic exchange of benefits is the plea for a price.

One might pause to wonder why a society which prides itself in its commercial tradition finds the word "price" so shameful in this context. Surely in this, as in any other usage, the term denotes no more than that point at which the parties, taking all their common and opposing interests into account, find a mutually acceptable meeting of surrender and gain. To an economist, the application of market theory to the criminal courts carries no disgraceful connotations. A description is a description. And the discovery that criminals

* The author expresses appreciation to James Scott Saunders, Esq., a young member of the New York Bar, for his assistance in the preparation of the footnotes to this article.

$\dagger$ Professor of Law. Columbia Law School.

1. For a description and criticism of plea bargaining practices in New York and Philadelphia, see White, A Proposal for Reform of the Plea Bargaining Process, 119 U. PA. L. Rev. 439 (1971). 
weigh advantages and risks in making important decisions, or that prosecutors and judges also think in "cost-benefit" terms, is not shocking. A courtroom is not, after all, a church. People do not plead guilty to save their souls by confession and repentance. Let us not shrink from integrating the guilty plea into the framework of all other legal decisionmaking-an event demanding only the cool, informed, and open appraisal of fair consequences, fairly supervised and enforced by judicial authority.

Actually, the guilty plea-and even the "bargaining" process that precedes it-has acquired a certain degree of respectability, in legal circles at least. ${ }^{2}$ Once thought of as the antithesis of litigation, hardly worthy of the services of counsel $^{3}$ much less the lofty attention of the guardians of the Constitution and their scholarly advisers, the guilty plea has come out of the closet. The Supreme Court (setting the mood as usual) has spoken approvingly of plea bargaining, ${ }^{4}$ a number of academic contributions have appeared, ${ }^{5}$ and the draftsmen of model codes have included the topic on their agenda. ${ }^{6}$ The efforts of this latter group, unfortunately, have usually produced rather pale copy, treading as they do warily in the footsteps of the Court decisions and the products of their rivals. The modest purpose of the present endeavor is to suggest some pertinent considerations largely overlooked by the model makers, though familiar enough to the practictioner in the temple/bazaar of justice.

Inspired by Boykin $\%$. Alabama ${ }^{7}$ and Rule 11 of the Federal Rules of Criminal Procedure, ${ }^{8}$ model makers and courtroom judges lavish considerable

2. See note 4 , infra.

3. Of course, one must go back more than twenty years to discover such a benighted era. See Herman v. Claudy, 350 U.S. 116 (1956).

4. Of the many decisions dealing with guilty pleas over the years, the most direct acceptance of negotiated settlements was pronounced in Santobello v. New York, 404 U.S. 257 (1971) where the Chief Justice said: "The disposition of criminal charges by agreement between the prosecutor and the accused, sometimes loosely called 'plea bargaining,' is an essential component of the administration of justice. Properly administered, it is to be encouraged." $I d$. at 260 . For a rather idealistic condemnation of "plea bargaining," see Note, The Unconstitutionality of Plea Bargaining, 83 HaRv. L. REV. 1387 (1970).

5. No study of the pleading process is complete without careful consideration of the observations and analysis of Professor Donald J. Newman in a report of an empirical study conducted under the auspices of the American Bar Foundation of the law and practice in Michigan, Wisconsin, and Kansas relating to guilty pleading in 1956 and 1957. The work contains valuable data and thoughtful commentary on many of the topics treated in the present paper. D. NEwMAN, Conviction: The Determination of Guilt or Innocence Without Trial (1966).

6. The "models" to be examined here are four: ABA Project on Standards for Criminal Justice, Standards Relating to the Administration of Criminal Justice (1974); American Law Institute, Model Code of Pre-Arraigiment Procedure (1975) [hereinafter cited as Pre-Arraignment Procedure]; Nat'l Advisory Comm' on Criminal Justice Standards and Goals, Courts Report (1973) [hereinafter cited as NAC Courts RePorT]; Nat'l Conference of Comm'rs on Uniform State Laws, Uniform Rules of Criminal Procedure (1974) [hereinafter cited as UNIFORM RULES].

7. 395 U.S. 238 (1969).

8. (e) Plea Agreement Procedure. 
attention upon the fateful moment of pleading, taking elaborate care to produce a rich record of the transaction in the official minutes. Judges laboriously explain to the counseled defendant who has indicated his choice to plead guilty that by doing so he is waiving his right to stand trial, to hear and cross-examine witnesses against him, and to remain mute on the accusation if he wishes to. In the wake of Henderson $\because$ Morgan $^{9}$ the litany will doubtless be expanded to inform the defendant of the legal elements of the crime to which

(1) In General. The attorney for the government and the attorney for the defendant or the defendant when acting pro se may engage in discussions with a view toward reaching an agreement that, upon the entering of a plea of guilty or nolo contendere to a charged offense or to a lesser or related offense, the attorney for the government will do any of the following:

(A) move for dismissal of other charges; or

(B) make a recommendation, or agree not to oppose the defendant's request, for a particular sentence, with the understanding that such recommendation or request shall not be binding upon the court: or

(C) agree that a specific sentence is the appropriate disposition of the case.

The court shall not participate in any such discussions.

(2) Notice of Such Agreement. If a plea agreement has been reached by the parties, the court shall, on the record, require the disclosure of the agreement in open court or, on a showing of good cause, in camera, at the time the plea is offered. Thereupon the court may accept or reject the agreement, or may defer its decision as to the acceptance or rejection until there has been an opportunity to consider the presentence report.

(3) Acceptance of a Plea Agreement. If the court accepts the plea agreement, the court shall inform the defendant that it will embody in the judgment and sentence the disposition provided for in the plea agreement.

(4) Rejection of a Plea Agreement. If the court rejects the plea agreement, the court shall, on the record, inform the parties of this fact, advise the defendant personally in open court or, on a showing of good cause, in camera that the court is not bound by the plea agreement, afford the defendant the opportunity to then withdraw his plea, and advise the defendant that if he persists in his guilty plea or plea of nolo contendere the disposition of the case may be less favorable to the defendant than that contemplated by the plea agreement.

(5) Time of Plea Agreement Procedure. Except for good cause shown, notification to the court of the existence of a plea agreement shall be given at the arraignment or at such other time, prior to trial, as may be fixed by the court.

(6) Inadmissibility of Pleas, Offers of Pleas, and Related Statements. Except as otherwise provided in this paragraph, evidence of a plea of guilty, later withdrawn, or a plea of nolo contendere, or of an offer to plead guilty or nolo contendere to the crime charged or any other crime, or of statements made in connection with. and relevant to, any of the foregoing pleas or offers, is not admissible in any civil or criminal proceeding against the person who made the plea or offer. However, evidence of a statement made in connection with, and relevant to, a plea of guilty, later withdrawn, a plea of nolo contendere, or an offer to plead guilty or nolo contendere to the crime charged or any other crime, is admissible in a criminal proceeding for perjury or false statement if the statement was made by the defendant under oath, on the record, and in the presence of counsel.

(f) Determining Accuracy of Plea. Notwithstanding the acceptance of a plea of guilty, the court should not enter a judgment upon such a plea without making such inquiry as shall satisfy it that there is a factual basis for the plea.

FeD. R. Crim. P. 11(e). For a description of the revised rule, see Note. Revised Federal Rule 11: Tighter Guidelines for Pleas in Criminal Cases, 44 FordhaM L. REv. 1010 (1976). See also McCarthy v. United States, 394 U.S. 459 (1969).

9. 96 S. Ct. 2253 (1976). 
he is pleading. Unobjectionable formalities. The mere presence of counsel does not necessarily assure that the defendant has been well counseled, and no harm is done when even the most obvious propositions are reiterated from the bench. But there are surely more-and more troublesome-components to this common event in the adjudication of criminal cases.

The three largest questions (or at least the three large questions to be addressed here) ${ }^{10}$ are: (1) How is the agreement arrived at? What are the legitimate and illegitimate considerations and conditions upon which the offer is made and accepted? Where do the normal pressures of self-interest shade into intolerable inducements that may deprive the choice of its "voluntary" character?" (2) Is the guilty plea supposed to be factually accurate, and what precautions are appropriate to preclude the conviction of the "innocent"? (3) How readily is the plea revocable by the unilateral choice of the defendant? Is the solemn entry of the plea, like a verdict, a firm determination of the charge not to be set aside except for good and urgent reasons, or is it-at least until sentence is pronounced upon it-but a manifestation of the defendant's state of mind, dispositive only so long as his resolve remains undaunted? Or is the contract binding only where prejudicial reliance can be demonstrated by the prosecution and, if so, what sort of prejudice should bind the defendant to his bargain despite a reasoned basis for reassertion of his right to trial?

\section{Development and Terms of the Plea}

The overriding factor detracting from the dignity and legitimacy of "plea bargaining" is surely the stubborn problem of calendar congestion and docket management. If justice suffers from excessive leniency, if defendants feel that they are "pressured" into pleading guilty and cheated of a meaningful "day in court," the villain is the economic necessity for maintaining a plea disposition rate of 90 per cent or better. In many jurisdictions it still appears that, despite heroic efforts, court time is simply not available on anything approaching a current basis for full-scale trials of more than the scantest proportion of felony charges. Thus, the swift trial remains an elusive goal in many places, and the new indictments come pouring down. Calendar "clearance" needs become urgent necessities. If, hypothetically, an acceptably free choice would produce guilty pleas in about half the cases, the evil resides in the means of

10. It might be remarked that I do not address directly the central components of the guilty plea: its knowing and voluntary character. This portion of the garden seems relatively well tended by both model makers and commentators and in need of no additional watering from me.

11. Several forms of prosecutorial and judicial inducements were examined against traditional criteria of "knowing" and "voluntary" choice in Comment, Official Inducements to Plead Guilty: Suggested Morals for a Marketplace, 32 U. CHI. L. Rev. 167 (1964). 
inducing the next 40 per cent or so to throw in the towel. ${ }^{12}$ But insofar as this problem sounds in terms of budgeting or efficiency, or even the radical revision of the traditionally leisurely pace of the trial process, it is mercifully beyond the scope of the present paper.

\section{A. Necessary Conditions of Waiver}

Normally, a guilty plea automatically forecloses a number of avenues of contention, in addition to waiving the right to challenge the substance of the accusation by trial. ${ }^{13}$ Inasmuch as these barriers to further litigation are the legal consequences of the plea itself, they are necessary conditions and do not enter into negotiations between the parties. But the model makers, so concerned with the processes of negotiation and plea taking, seem to have given little thought to the wisdom of the law in building these various bars into the guilty plea. In the absence of saving statutes, ${ }^{14}$ motions of several different sorts, made and lost beforehand, are lost forever by virtue of the guilty plea. Among them are challenges (on grounds other than jurisdiction) to the indictment. These may rest on statutory claims such as the insufficiency of the underlying evidence or flaws in the procedure of accusation or the drafting of the instrument, or they may sound in constitutional terms such as unwarranted exclusions in the composition of the grand jury. ${ }^{15}$ Too, lost motions may look to the future trial on statutory grounds such as the motion for severance, or constitutional bases such as the motion to exclude evidence obtained in violation of basic protections. ${ }^{16}$

Since the denial of motions of this sort is usually reviewable on appeal from a judgment of conviction predicated on a verdict, the guilty plea may be said to waive appellate rights along with the right to trial. Passing the odd omission in the meticulous models of any requirement that the pleading de-

12. A colleague and member of the New York Bar has submitted a provocative study purporting to demonstrate statistically from data from twenty-nine federal districts that about twothirds of the "marginal" defendants pleading guilty would not have been convicted had they stood trial. This finding is juxtaposed against the (questionable) premise that the Supreme Court tolerates guilty pleas on the assumption that they are reliable predictions of trial outcome. On this basis, the article calls for reexamination of methods of inducing guilty pleas in high volume jurisdictions. Finkelstein, A Statistical Analysis of Guilty Plea Practices in Federal Courts, 89 Harv. L. Rev. 293 (1975).

13. Tollett v. Henderson, 411 U.S. 258 (1973); Parker v. North Carolina, 397 U.S. 790 (1970); McMann v. Richardson, 397 U.S. 759 (1970); Brady v. United States, 397 U.S. 742 (1970).

14. Lefkowitz v. Newsome, 420 U.S. 283 (1975)

15. See Tollett v. Henderson, 411 U.S. at 258.

16. In a rather odd twist, the Court of Appeals for the Sixth Circuit reluctantly honored an express term of a guilty plea bargain by which the defendant reserved the right to challenge on appeal an adverse ruling on his pretrial motion to suppress evidence, a term in direct derogation of the general rule. United States v. Cox, 464 F.2d 937 (6th Cir. 1972). The court honored the agreement in the case before it on the grounds that a refusal to do so would constitute a failure of consideration within the plea bargaining process. However, it announced that this procedure would not be countenanced in the future. Id. at 945-46. 
fendant be informed of and expressly surrender rights of this order, the larger question is the advisability of such broad waivers of appellate review and the absence of any suggested modification among the models' recommendations.

While any limitation on litigation may enjoy a value in itself, it can not be permitted to prevail at all costs. Nor can it be fairly said that a major virtue of the guilty plea is its final termination of contention in the case. The judgment is subject to (and commonly subjected to) challenge by collateral writs, as well as by direct appeal from denials of subsequent applications to withdraw the plea. Moreover, it may well be asserted that allowing post-plea appeals from certain lost motions actually effects an economy in court time. A defendant whose only point is a legal one, and who believes (with his lawyer's aid) that his pre-trial challenge was erroneously disallowed, is forced by the automatic waiver rule to undergo a full-scale and wholly unnecessary trial in order to preserve what he hopes to be his dispositive point for appellate review. If the law of his jurisdiction permitted the point to survive a guilty plea, appellate attention would be no more costly than the time spent on it after verdict, and many needless days of trial time would be saved.

New York, and some other jurisdictions following her lead, took note of the arithmetic as well as the justice of awarding a limited appellate course to the pleading defendant, and provided appeals from denials of motions to suppress evidence where the judgment of conviction was entered upon a plea of guilty. ${ }^{17}$ If this statutory election is wise for New York, as it certainly appears to be,$^{18}$ it surely merits some comment from the model makers. Indeed, it may well be that the logic of surviving suppression issues could be applied with equal force and benefit to other lost motions, or at least to those standing on the stout limbs of constitutional predicates. ${ }^{19}$

17. N.Y. CrIm. Proc. LAw $\$ 710.70(2)$ (Mckinney 1971). The New York Court of Appeals approved the requiring of a waiver of the right to appeal from the denial of a suppression motion as a condition to the acceptance of a guilty plea. People v. Williams, 36 N.Y.2d 829, 331 N.E.2d 684,370 N.Y.S.2d 904, cert. denied, 423 U.S. 873 (1975).

18. This procedure was implicitly endorsed by Letkowitz v. Newsome, 420 U.S. at 283 . Insofar as Newsome deals with the availability of federal habeas in state cases where evidence was allegedly obtained by unconstitutional means, it has been superseded by Stonc v. Powell. $97 \mathrm{~S}$. Ct. 3037 (1976); Tushnet, More Disquiet in the Citadel, 26 Srracusf. L.. REv. 1227 (1975). See also Comment, Appellate Review of Constitutional Infirmities Notwithstanding a Plea of Guilty, 9 Housrox L. Rev. 305 (1971).

19. I do not here consider the chilling effect upon the right to appeal which might result from the refusal of a prosecutor to repeat his bargain offer when the case arrives back on remand after a defense victory in the appellate round. The question was briefed by Borman, The Chilled Right to Appeal from a Plea Bargain Contiction: A Due Process Cure, 69 Nw. U.L. Rev. 663 (1974). The Sixth Circuit Court of Appeals in Mullreed v. Kropp, 425 F.2d 1095 (6th Cir. 1970), held the lesser plea to be an implied acquittal of the greater charge and invoked the double jeopardy clause to bar reprosecution after successful collateral attack on the conviction. The decision receives criticism in Comment, The Constitutionality of Reindicting Successful Plea-Bargain Appellants on the Original Higher Charges, 62 CALIf. L. REv. 258, 272-79 (1974). 


\section{B. Negotiated Conditions of Waiver}

A defendant may, of course, plead guilty to the whole of a charge against him and hurl himself blindly upon the tender mercies of the court. Perhaps some do. But in today's sophisticated commerce in justice, such a leap of faith would seem reckless, if not foolhardy. While such a defendant may by luck fling himself into a merciful judicial lap, a few solid contractual terms worked out in advance by lawyers seems to most defendants a sounder way of doing business.

The usual terms are simple enough. For his part, the defendant agrees to waive trial. In exchange, the prosecutor agrees to settle for less than total victory. This he normally does in one or more of three ways:

1. Acceptance of a lesser plea. In every surrender-and especially where local statutes attach minimum sentences to certain crimes-a defendant prefers to have judgment entered against him on some offense of lesser gravity than the most serious charge in the indictment. In most jurisdictions, an indictment may not be disposed of on a plea to a reduced charge without the consent of the prosecutor. And an accord between the parties on a lesser plea is almost invariably accepted by the court. ${ }^{20}$ In the first instance, then, the defendant must secure the prosecutor's promise to recommend the acceptance of a lesser plea. Since felony indictments often contain several counts of differing severity, and many penal structures (with the notable exception of the federal code) are so constructed that lesser degrees of an offense are necessarily implied in the charge of a greater degree, the prosecutor and defendant's counsel usually have a wide range of available grades of crimes from which to select an appropriate disposition offense. That's where the bargaining comes in. ${ }^{21}$

2. Agreement not to prosecute other charges. Closely related to the lesser plea is the prosecutor's agreement to allow a judgment entered on a selected crime to "cover" all other crimes charged in the same or separate indictments. Since conviction on several of the "covered" offenses might allow consecutive sentences as well as greater terms than the maximum provided for the pleading crime, it might be thought that the defendant extracting such a concession from the prosecutor has made an unusually good deal for himself. And, indeed, if the covered crimes are unrelated (as, for example, three stickups of three different cabdrivers on three different days), it might be said that the defendant pleading guilty to one robbery charge to cover three had received two crimes "on the house." Yet such slate-wiping dispositions are extremely common (indeed they constitute virtually the only form of plea bargaining in

20. But see the unusual case of United States v. Ammidown, 497 F.2d 615 (D.C. Cir. 1973).

21. Would you believe that New York's highest court has held that a valid plea may be taken to an imaginary crime, devised by the parties and otherwise inconceivable to the penal law? See People v. Foster, 19 N.Y.2d 150, 225 N.E.2d 200, 278 N.Y.S.2d 603 (1967). 
the federal system). Though the defendant may feel with some satisfaction that he has cheated dame justice of her due, the severity and number of the actual crimes the defendant is believed to have committed (as well as other factors in his background) affect the selection of the crime to which he will be required to plead. They will also, under the scope allowed him by the appropriate plea crime, enter in the judge's choice of sentence.

3. Helpful intercession on the matter of sentence. While sentencing is the defendant's most pressing concern, it would seem to be a matter altogether out of the prosecutor's control. Yet, resourceful lawyers are not dismayed; ways can be found to put the matter into form for negotiation. As seen, the crime selected for pleading affects sentence at least insofar as it controls the maximum, and under some codes, the minimum as well. Under many modern statutes, however, judicial discretion remains relatively broad. Defendants seek by bargaining not only reduction in the time they will have to spend behind bars, but a better basis for predicting the concrete result of their plea and some shield, however imperfect, against the upper range of the sentences available under their plea. Thus, the prosecutor's recommendation concerning sentence has become an item of barter. The term of the plea contract may simply be that the prosecutor will abstain from recommending anything (a defendant convinced the prosecutor is out to hand him may be happy just to have him keep out of the sentencing decision). More often, the defendant bargains for the prosecutor's specific recommendation of an appropriate sentence (or at least maximum). While some prosecutors feel uncomfortable participating actively in a matter traditionally between the court and the defendant, such sensitivity to role limitations often yields to the expeditious alternative. In another form, the participation of the prosecutor in the sentence process may amount to an indication of consent to a definite sentence promise made in advance of the plea by the court to the pleading defendant (about which, more later). How much the prosecutor's recommendation or accord is worth is somewhat problematic and may vary with the judge, but the position of the prosecuting agency on the matter usually carries considerable weight. It is often easier for a court (particularly in an area as amorphous as sentence selection) to ratify an agreement between the parties than to shoulder sole responsibility for the choice. The slight diminution of judicial prerogative probably passes unnoticed.

These common categories of consideration for the defendant's plea find their way into the Standards Relating to Guilty Pleas promulgated by the American Bar Association Project where they receive the imprimatur of acceptability. ${ }^{22}$ The motion is seconded, rather casually, by the American Law Institute (ALI) in its magnum opus, the 1975 Model Code of Pre-Ar-

22. Aba Standards for Criminal Justice, Standards Relating to Pleas of Guilty $\$ 3.1$ (App. Draft, 1968). 
raignment Procedure. In describing the "Plea Conference," the Model Code states that the parties will meet at the request of either "to discuss the possibility that upon the defendant's entry of a plea of guilty or nolo contendere to one or more offenses, the prosecutor will not charge, will dismiss or will move for the dismissal of other charges, or will recommend or not oppose a particular sentence." ${ }^{23}$ And that's that. The ALI recognizes the common ingredients of the plea bargain as only "possibilities" to be "discussed," not as acceptable terms of an agreement. And, apparently, in the Institute's visualization of the scene, no other topic comes up for discussion at this conference. Or at least no other topic worth noting. (I don't suppose that, from this brief narrative of the purpose of the meeting, we are to conclude that no other conditions or concessions could lawfully be mentioned by the parties.) The section does go on to warn the prosecutor against trying to extort a guilty plea by charging or threatening to charge a crime unsupported by provable facts or the like. ${ }^{24}$ And here the National Advisory Commission (NAC) on Criminal Justice Standards and Goals loyally echoes the ALI. ${ }^{25}$ Could a blander set of imperatives be conceived of? Despite their evident concern with the development of dispositions by carefully regulated negotiation, the ABA, ALI, and NAC have nothing further to say on the appropriate terms and conditions of guilty pleas. These omissions may fairly be termed distressing.

The Uniform Rules of Criminal Procedure (URCP) adopted in 1974 by the National Conference of Commissioners on Uniform State Laws puts the same thoughts in somewhat different form. ${ }^{26}$ It provides that the parties may agree to condition a guilty plea on one or more of the following events. First, amendment of the accusatory instrument by the prosecutor "to charge a specified offense." This provision appears to assume that the prosecutor may alter indictments and insert new charges at will, and with no firmer basis in the facts than the contract between the parties. For jurisdictions still insisting on grand jury charging, or holding that a criminal charge must be premised on a prima facie case, this sort of rewriting of formal instruments to suit the settlement between the parties must be deemed inimical. And what a strange way to provide that the prosecutor may agree to disposition by plea to a lesser included crime, if that is what is meant. The second paragraph allows the condition that the prosecutor will dismiss or "not bring" other charges. Straightforward enough, once one accepts the seemingly absolute charging authority in the prosecutor. The third condition deals with sentence. For reasons not altogether clear in the commentary, the provision prefers not to speak in terms of recommendations (perhaps because they are not binding)

23. Pre-Arraicnment Procedure $\$ 350.3(1)$.

24. Id. $\$ 350.3(3)$.

25. NAC Courts RePort $\$ 3.6$.

26. UNiform Rules 443(a). 
but rather allows the plea to be conditioned on the actual receipt of a sentence of not more than the term agreed upon. This goes a fair way toward taking the judge off the bench entirely, for if he exceeds the sentence agreed upon by the parties he automatically cancels the previously (and carefully) entered plea. Pretty close to the usurpation of law by contract.

One of the several oddities of this draft is that the commentators regard it as similar to the Model Code of the American Law Institute relating to PreArraignment Procedure, section 320.5(1)(e)\&(f). ${ }^{27}$ The section cited, however, has nothing to do with guilty pleas but provides for alternate dispositions. Article 350, Procedure Relating to Guilty Pleas, (at least in the Approved Draft) contains nothing remotely resembling the URCP formulation. ${ }^{28}$

Most interesting in the URCP proposal is the fourth and final condition permitted for a guilty plea. It provides that the defendant will not seek appellate review of an order denying a pre-trial motion. It is an interesting addition largely because it is the only thought addressed by any of our four models to the question of permissible concessions to be exacted from the defendant in addition to his waiver of the trial. To be sure, it is rather crude and its merits are questionable, but at least it demonstrates that someone gave a passing thought to an issue which this paper will shortly argue is a major one in the matter of negotiated terms of disposition.

The URCP's ill-conceived fourth allowable condition must be read in conjunction with Rule 444(d). By that provision, orders denying suppression of evidence or "any pretrial motion which, if granted, would be dispositive of the case" are exempted from the general proposition that a guilty plea bars review of non-jurisdictional defects. It is this specially accorded reservation of the right to appeal which Rule 443 allows the defendant to surrender as a condition of his plea. Even a first offender could see the sleight of hand here.

Apart from its cuteness, this provision does provide a springboard to our consideration of the looming questions unnoticed by our four model makers. Here they come. When a prosecutor and defense counsel sit down to develop a settlement, are all the defendant's rights, constitutional and statutory, as well as all his future acts and forbearances, on the table for barter? And if not, where in the name of law or sound policy should the limit be drawn? Perhaps a defendant may be allowed to surrender such special right of post-plea appeal as he was awarded by statute, but should he be permitted to bargain away vital protections, including those affecting the very integrity of the proceeding, such as double jeopardy, the right to counsel, or denial of a speedy trial?

While it is clear that the waiver of the right to trial is no less voluntary

27. Uniform Rules 443(a), Comment.

28. Pre-Arraignment Procedure $\$ \$ 350.1-7$. 
because it was made to obtain the benefits of a plea bargain, ${ }^{29}$ the question is whether there are some antecedent or future rights of such a distinct character of such special systemic importance that a guilty plea should not be conditioned on their surrender. The right to trial, with all it implies, is necessarily abandoned by a plea. And it might be argued that the election to plead guilty might be reasonably coupled with the abandonment of challenges to the admissibility of evidence otherwise necessary to convict by trial. ${ }^{30}$ Thus, perhaps a prosecutor might offer to recommend a reduced disposition only if the defendant pleads guilty without making motions to suppress trial evidence (this, of course, wholly apart from the pragmatic wisdom of allowing the issue in a defeated motion to survive the plea).

The Supreme Court, however, has indicated that there is something notably different about defects in what it terms the power of the state to hale the defendant into court. Double jeopardy, the Court determined, destroys the haling power to such an extent that the guilty plea loses its potency. ${ }^{31}$ This being the case, perhaps the power to hale the defendant may not be reconstituted by contract and the defendant can not be convicted upon his consent not to raise the claim that his prosecution violates double jeopardy. If such a term in a plea bargain is invalid and unenforceable, perhaps others relating to the haling power are equally unavailable for barter. The New York Court of Appeals, for example, has held that, because of the nature of the right, a prosecutor's offer of a lesser plea on condition that a defendant withdraw his speedy trial claim is inherently coercive, and the judgment predicated thereon must be vacated ${ }^{32}$

Actually, with deference to the Supreme Court which has put the matter in these terms, the haling power does not seem to be the happiest rubric for

29. For a thoughtful analysis of the concept of waiver as enunciated in the so-called "Brady trilogy" (Brady v. United States, 397 U.S. 742 (1970); McMann v. Richardson, 397 U.S. 759 (1970); Parker v. North Carolina, 397 U.S. 790 (1970)), the treatment it received in the lower courts and the limited departure marked by Blackledge v. Perry, 417 U.S. 21 (1974), see Note, The Guilty Plea as a Waiver of "Present but Unknowable" Constitutional Rights: The Aftermath of the Brady Trilogy, 74 Colvm. L. Rev. 1434 (1974). Intense analysis of the famous "trilogy" is also afforded by Alschuler, The Supreme Court, the Defense Attorney, and the Guilty Plea, $47 \mathrm{U}$. CoLo. L. REv. 1 (1975).

30. In a most interesting footnote to its per curiam opinion in Menna v. New York, 423 U.S. 61 (1975), the Court offered a rationale for its different results in the Tollett-Brady group and the Perry-Menna cases. The point, they say, is not the waivability of the claim of double jeopardy as such. Rather, the crux of the Brady line is that a counseled plea of guilty, being an admission of factual guilt, validly removes that issue from the case and affords a sufficient basis for the imposition of punishment. "A guilty plea, therefore, simply renders irrelevant those constitutional violations not logically inconsistent with the valid establishment of factual guilt." $I d$. at 62-63 n.2. Where. however, the claim on its face is such that the state may not prosecute regardless of factual guilt, the guilty plea does not bar the assertion of the claim.

31. Menna v. New York, 423 U.S. 61 (1975); Blackledge v. Perry, 417 U.S. 21 (1974).

32. People v. Blakley, 34 N.Y.2d 311, 313 N.E.2d 763, 35 N.Y.S.2d 459 (1974). See also People v. White, 32 N.Y.2d 393, 298 N.E.2d 659, 345 N.Y.S.2d 513 (1973). 
identifying defects of this special sort. Defects of jurisdiction, like double jeopardy and speedy trial, go to the power to hale the defendant into court and, like them, override the guilty plea. But the Court has held that a constitutional defect in the composition of the grand jury-which would also appear to undermine the validity of the process by which the defendant is called to court-yields to the guilty plea. ${ }^{33}$ And there may well be other rights, not associated with the haling power, which may not be abandoned by the plea agreement. For example, waiver of the right to be represented by counsel at the adjudication, a waivable right in itself, should not be made a condition for the acceptance of a lesser plea. Notice of the charges to which the defendant is called upon to plead might be another right which a defendant may not be induced to forego in exchange for the recommendation of a plea.

And apart from cancelling legal issues, to what extent is it proper for the prosecutor to apply the heavy leverage of his office to rewrite the defendant's life, ordering him to marry his pregnant "victim," change his occupation, move out of the jurisdiction, or who knows what in exchange for the break he seeks? Can the prosecutor condition his recommendation on hazardous though useful activity by the defendant, such as "cooperation" in the investigation or prosecution of other criminals? Can he demand harmless though useless conduct such as getting a haircut? Or can the prosecutor properly set a condition wholly beyond the control of the defendant affected, such as: "I will recommend the acceptance of this plea but only if all your co-defendants decide to plead guilty too?"

Even when we tether imagination firmly to reality and remain well within the ambit of common experience, the questions multiply rapidly. ${ }^{34}$ To sort them out and offer guidelines for answering them is beyond the ambition of this paper (though it is tempting). One might have thought that that is why we have model makers.

\section{Pre-Plea Discovery}

In addition to demanding and yielding terms of various sorts in the negotiation, the parties customarily exchange factual data about the case. Termed "informal discovery," the process is sometimes cited as a reason why expanded and enforced procedures for formal discovery are unneeded in criminal cases. Yet, the informal method is a capricious device, varying in character with local tradition, the attitudes of individual prosecutors, and the "old boy" status or personal reputation of a particular defense attorney. Too, the process is necessarily selective. Even the most scrupulous and conscien-

33. Tollett v. Henderson, 411 U.S. 258 (1973).

34. May a prosecutor induce a plea by a promise not to prosecute the defendant's wife or fiancee? Compare Kent v. United States, 272 F.2d 795 (1st Cir. 1959), with Crow v. United States, 397 F.2d 284 (10th Cir. 1968). 
tious counsel are in some degree responsive to their purposes in the negotiation. Of course, full and accurate disclosure by the prosecutor may, in most cases, best serve his prime purpose to persuade the defendant and his counsel that a court battle would be futile. In these instances (and where the prosecutor believes that tampering with his evidence is an unlikely consequence of early divulgence), it may be that informal communication could not be improved upon. But what if the prosecutor harbors some information adverse to his position?

It is surely clear at this stage in the maturity of our adversary system of justice that a prosecutor is legally and ethically obligated to make known to the defense any adverse fact he knows, and does not intend to adduce, in time to allow the defense to put it before the fact finder if he wishes. Concealment of known or knowable evidence which might affect the verdict incurs an intolerable risk of false conviction. But do the identical obligations of pre-trial disclosure of evidence govern the pre-pleading process?

Adverse information in the prosecutor's hands may be of different sorts and significance. The three major types of material are: (1) exculpatory evidence, testimonial or physical, on the merits of the accusation; (2) matters bearing negatively on the credibility of a prosecution witness; and (3) facts affecting the triability of the case (such as the unavailability of a witness). The significance of such data is not a constant. The existence of a credible witness who contradicts material testimony on the merits may raise a question concerning the culpability of the accused. On the other hand, a relatively trivial misdeed in the background of a prosecution witness, while available to impeach his credibility, may have little effect on the truth of the accusation. So too, the death or disappearance of a wirness may not detract from the force and veracity of his account. Somewhere in between may be the common fact, known only to the prosecutor, that in the course of the development of the case, a witness altered his story in some respects, ultimately coming to the version which the prosecutor concludes from other sources to be the accurate rendition.

The extent to which the prosecutor is bound to divulge such information prior to the defendant's decision to plead guilty depends largely on one's view of the nature of the litigation process. If it is (as we are fond of declaiming) a "search for the truth," then all matters affecting the persuasiveness of the prosecution case should be irrelevant. A guilty plea is, after all, a confession of culpability, or at least a voluntary consent to suffer judgment. And the conviction founded on that basis is not impaired by any weakness in the trial evidence which the prosecutor could have adduced had the issue of guilt been contested. If any protection against false confessions is needed, it might be supplied by the bona fides of the accusation plus the good faith belief of the prosecuting officer that the charge is true. On the other hand, if the process 
is viewed more as a test of strength in which the guilty plea represents an informed prediction of the likely outcome of a trial, the necessity of advance disclosure of trial weakness becomes a critical factor in the validity of the plea.

The ALI Model takes the bull by the horns, providing that prior to any plea agreement "the prosecutor shall disclose to the defendant sufficient information within his knowledge to enable the defendant to make an informed assessment of the likely outcome upon a trial of the case." 35 The American Bar Association, devoting a volume of Standards entirely to discovery, also perceived the need for enhancing prediction for plea purposes, but did not speak of matters bearing only on the triability of the case. Among its "General Principles," in Discovery Standard 1.1, the ABA lists the purpose of providing the defendant "sufficient information to make an informed plea." And under Standard 2.2, the prosecutor is directed to perform his obligations of disclosure as soon as possible after the filing of charges-clearly during plea discussions. But, except for one matter relating to impeachment of prosecution witnesses-prior criminal record ${ }^{36}$-all specified items for defense discovery consist of information regarding evidence in the case or the means of its acquisition.

In summary fashion, the National Advisory Commission acknowledges the duty of pre-plea disclosure. Among "Prohibited Prosecutorial Inducements to Enter a Plea of Guilty," the NAC includes "[f]ailing to grant full disclosure before the disposition negotiations of all exculpatory evidence material to guilt or punishment." ${ }^{37}$ The accompanying commentary limits the intent of this provision to the obligatory disclosure of materials covered by Brady $"$. Maryland. ${ }^{38}$ Not very generous. The Uniform Rules of Criminal Procedure deal with discovery at considerably greater length, but they do not specify disclosure before pleading negotiation. Time for disclosure is governed by either the defendant's request or the direction of the court. Though it may be contemplated that discovery should aid the pleading process, that purpose is not explicit. Nor does the URCP design cover matters bearing on the credibility of prosecution witnesses or impediments to triability.

\section{Participation of the Court and the Sentence Promise}

Finally, in the development of the plea agreement, let us consider the proper role of the judge. The models are nearly unanimous in the flat declaration that the court should not participate in the plea negotiations. The

\footnotetext{
35. Pre-Arraignment Procedure $\$ 320.3(1)$

36. Aba Standards for Criminal Justice, Standardo Relating to Discovery and Procedure Before Trial $\$ 2.1$ (a)(vi) (App. Draft, 1970).

37. NAC COURTS REPORT $\$ 3.6$.

38. 373 U.S. 83 (1963).
} 
ABA, ${ }^{39} \mathrm{NAC}^{401}$ and URCP41 formulations say so in as many words, and ALI strongly implies it. ${ }^{42}$ Of necessity, all models allow the submission of a plea agreement to the court before the plea is tendered and the expression of accord or disapproval by the court. But this is apparently the tolerable limit of his "participation."

Rule 11 of the recently revised Federal Rules of Criminal Procedure contains a similar restriction on the participation of the trial judge in plea discussions. In May of 1976, the occasion arose for the Court of Appeals in the Second Circuit to consider the prohibition against judicial participation in its most important application. In United States 21. Werker, ${ }^{43}$ a district court judge, after inspecting a probation report, proposed to inform defense counsel before the plea of the sentence he had in mind for the defendant. Upon the prosecutor's suit for mandamus, the circuit court enjoined the trial judge, holding that the disclosure of intention would violate Rule 1 l's categorical prohibition against participation. Even without the rule, the court noted, they would reach the same result on the grounds that such premature communication might exert subtle but improper pressure on the defendant's plea decision. ${ }^{44}$ While it is unfortunate that the models do not afford equally explicit expressions on the application of their injunctions to the express preplea sentence promise, it probably may be fairly assumed that the framers had in mind precisely this sort of participation by the court.

One cannot help but wonder what great principle unites the model makers and a leading circuit bench in such fine accord, particularly when many jurisdictions (including the state courts in New York) regularly permit the trial judge to offer the defendant the benefit of the court's thinking on the question of sentence. When a trial judge has informed himself of the defendant's background and the circumstances of his crime, when he has formed at least a tentative decision on the appropriate sentence, and even (according to some) when the sentence concession is not contingent on the plea but would be followed even if the defendant elected to be tried, ${ }^{45}$ what interests of the defendant are protected by prohibiting the judge from communicating this

\footnotetext{
39. Standards Relating to Pleas of Gullty, supra note 22, § 3.3(a).

40. NAC Courts RePort \$ 3.7.

41. LNIFORM RULES 44 l(a).

42. Pre-Arraignient Procedure $\$ 350.3(5)$.

43. 535 F.2d 198 (1976).

44. Id. at 203 .

45. See NAC Courts REPORT $\$ 3.8$, advising that the fact that the defendant pleaded guilty is not to be taken into account in arriving at the appropriate sentence. In proposing that leniency is an impermissible response to a guilty plea, the provision radically departs from ancient and prevalent practice. For a study of judicial attitudes. see Comment, The Influence of the Defendant's Plen on Judicial Determination of Sentence, 66 YALE. L.J. 204 (1956). Since leniency for plea implies penalty for trial, a good and logical argument might support the idea of a neutral plea of guilty. "Visionary" is not the worst that can be said of a model maker.
} 
information to him? Unless it be what one commentator termed the defendant's right to "plead in the dark." 46

Is it not odd, is it not essentially inconsistent to insist (as do the models) that the defendant base his plea on an intelligent assessment of the strengths and weaknesses of the prosecution case-fully disclosed to him in advance - while precluding the judge from revealing to him the single most important consequence of his plea: the sentence? A blind act of confession and contrition is one thing, an informed balancing of risks and advantages is quite another.

Behind the recommendation restricting the participation of the judge appears to be the dual concern that the judge might prejudice himself in the case by partaking in the preliminary discussion (particularly if he continues to preside after the defendant's rejection of the plea), and that the defendant might be persuaded by the court's expressed attitude to plead guilty where either his innocence or ignorance would otherwise have led him to choose a trial. ${ }^{47}$ Though it may be wise in a model to caution a judge against persuasion or prejudice, surely most members of the judiciary could understand an injunction against attempting to influence the defendant's decision or be influenced by it without excluding them altogether from "participation."

For the reality is that, in the guise of shielding defendants from undue pressure, the models deprive them of a vital component in their assessment of their options. Most defendants contemplating a guilty plea want to know, need to know, and (it is respectfully submitted) are entitled to know the sentence or the upper limits of the sentence they face in those instances where the judge can fairly predict his disposition at the time of the plea. There should be no greater mystery about the judge's view of an appropriate penalty than the district attorney's judgment regarding an appropriate crime for pleading purposes. In ratifying the prosecutor's proposed recommendation of a lesser offense, the court, in effect, agrees to a reduction in the gravity of the full charge, and with it a reduction in the maximum punishment. Where possible in advance, greater specificity does not further compromise judicial discretion nor the defendant's freedom to choose a trial. In the interests of promoting an intelligent choice, it would have been wiser had the models addressed directly the manner and circumstances in which a judge might add

46. Comment, supra note 11 , at 183 .

47. A member of the Dade County, Florida, Public Defender's staff believes that sentence promises are subtly coercive and "participation by even the most fair minded judges in plea negotiation is likely to devastate a defendant's volition." She also deems it "highly unlikely" that a judge could preside impartially over the trial of a defendant who had rejected a sentence concession. Gallagher, Judicial Participation in Plea Bargaining: A Search for New Standards, 9 Harv. Civ. Rights-Civ. LiB. L. Rev. 29, 43-44 (1974). For a contrary view favoring greater judicial participation, see Note, Restructuring the Plea Bargain, 82 Yale L.J. 286 (1972). See also Note, Judicial Participation in Guily' Pleas-A Search for Standards, 33 Pitt. L. Rev. 151 (1971). 
relevant information to the defendant's understanding of the probable consequences of his waiver of the right to trial.

Unstated, but activating the federal rule and the proscription in the models, may be another consideration. The worthy guardians of the process were probably concerned with the "dignity" of the bench. Lingering distaste for the business of settlement and compromise in criminal cases may have led them to try to preserve the judicial skirts from the mud of the marketplace. To contribute to the discussions between counsel is regarded as "stooping" to the position of litigants with irreparable loss to the mystique of aloof detachment. Yet a good judge is anything but passive in the important aspects of justice. He is not a mere spectator in the case, for the performance of defense counsel and the prosecutor as they develop a disposition is very much the concern of the court. Prohibiting all participation by the judge in this crucial matter is to demean his wisdom, talent, and authority. In the final analysis, the blanket proscription insults the very dignity of the court it seeks to promote.

11

The Factual Accuracy of the Plea

In the not-so-distant days of our naïveté, we were not greatly concerned about the factual basis of a conviction by guilty plea. The formal instrument of accusation was in itself thought to provide a reliable foundation for the plea, having been subject to judicial test by preliminary hearing and/or review of the quantum of proof before a grand jury in serious cases. In most jurisdictions, it could be fairly presumed that the charge met the measure of probable cause, if not prima facie proof. Coupled with the presumptive or adjudicated basis for the charge, the confession of the defendant, implicit in his plea, was believed to accord adequate assurance that the judgment reflected the true facts.

Though the confession is a component of this formula, an express oral recitation or even acknowledgment of the culpable facts was not generally required. To some judges, the willingness of a defendant to confess was regarded as a token of repentance and a natural part of a plea for mercy. Defendants obliged, of course. The oral confession allowed other judges to boast to their consciences that they imposed punishment only upon those who owned they deserved it. Again the canny defendant would play his assigned part. But the gradual adoption of a pleading routine including the defendant's admission of culpable particulars probably served a more pragmatic purpose. Courts began to experience an annoying return of concluded cases. Defendants, seeking to undo their pleas, would commonly assert factual innocence in a motion to withdraw the plea or in a later attack on the judgment by writ. Obtaining an express declaration of culpability at the time of the plea 
afforded an expeditious means of rejecting such later professions of innocence.

Thus, even before Boykin condemned the silent pleading record, ${ }^{48}$ many courts required that a defendant on voir dire personally confess his guilt before pleading guilty. Yet, the insistence on these oral declarations had little to do with strengthening the factual basis for the plea, or assuring its factual accuracy. Indeed, one might readily suspect that the regular demand for confession as a prerequisite to a desired concession in the disposition of the case produced more than a few disingenuous acknowledgments of culpable facts, particularly when a busy judge avoided the defendant's discursive narrative by posing leading interrogatories.

From time to time, the importance of the component of confession has been tested by a defendant who, while earnestly seeking to avail himself of the tendered plea offer, was unwilling or unable to admit some essential element of his guilt. ${ }^{49}$ Perhaps he had difficulty declaring his criminal intent, perhaps he refused to omit a description of circumstances which, if believed, would amount to a defense. Should the judge be informed of this hitch beforehand by defense counsel, or should he discover it himself during the voir dire, what is he to do? Is it enough that he is persuaded that the defendant's plea choice is voluntary and intelligently made after full advice of counsel? Can the system tolerate a guilty plea from a person who refuses to admit or-worse-denies his culpability? Will we sanction the punishment without a trial verdict of a defendant who declines himself to resolve the issue of his guilt created by the accusation and the "presumption of innocence"? Are we able to regard the guilty plea as mere intelligent capitulation, the willing consent to be treated as a criminal?

To this hard question, many trial judges have answered from their own consciences: no, they could never condemn a person who had been adjudged guilty neither by his peers nor by himself. (Of course, the judge would sit as a fact finder if the defendant requested it, but then his judgment would be based on evidence demonstrating guilt beyond a reasonable doubt.) The result of such conscientious scrupling is either: (1) the defendant learns that justice demands that he must lie to get a break, or (2) because of his (putative) innocence, he must go to trial on the full charge and face more severe punishment if convicted. To say piously that those who insist on their innocence will be accurately judged on trial is to exhibit a gleaming but foolish faith in the omniscience of the fact finder. A strong prosecution case is a strong case regardless of the defendant's protestations. And an attractive plea

48. Boykin v. Alabama, 395 U.S. 238 (1969).

49. This difficult situation was addressed in theoretical terms by Christie \& Pye, Presumptions and Assumptions in the Criminal Law: Another View, 1970 Duke L.J. 919, 922-33. 
offer is no less attractive because of the defendant's contrary version of the facts.

For practitioners, participating in the conviction of a person who refuses to condemn himself is probably less troublesome. Perhaps experience has led them to doubt the veracity of a client's exculpatory account, understanding the human need to invent and believe circumstances of self-justification. Perhaps they have sat too often and watched a strong defense go under at trial. Perhaps their vantage simply makes them more practical than judges, imbuing them with less regard for the contents of such formal rituals as the voir dire than for the tangible advantages of a well-made bargain in a losing cause. Whatever the reason, few defense lawyers would balk, despite some strong judicial instructions, ${ }^{50}$ at permitting a client to plead guilty though he would not confess guilt. Indeed, one suspects that to obtain the benefit of the plea, some lawyers countenance a client's oral admission to a judge known to require it, though the defendant privately maintains to his counsel that it is untrue. $^{51}$

When the Supreme Court came up against the problem, they boldly declared that, although a confession was normally a part of a guilty plea, it was not essential to its validity. In North Carolina $\%$. Alford,$^{52}$ the Court noted that state and lower federal courts had divided on the issue, and remarked that "[o]rdinarily, a judgment of conviction resting on a plea of guilty is justified by the defendant's admission that he committed the crime charged against him and his consent that judgment be entered without a trial of any kind. The plea usually subsumes both elements, and justifiably so . . .".53 But the Court recalled that "[i]mplicit in the nolo contendere cases is a recognition that the Constitution does not bar imposition of a prison sentence upon an accused who is unwilling expressly to admit his guilt but who, faced with grim alternatives, is willing to waive his trial and accept the sentence." ${ }^{54}$ Seeing no constitutional significance in the different denominations of the plea, or in the distinction between a mute plea and a claim of innocence, the Court concluded: $:^{55}$

When his [Alford's] plea is viewed in light of the evidence against him, which substantially negated his claim of innocence and which further provided a means by which the judge could test whether the plea was being intelligently entered, . . . its validity cannot be seriously questioned. In view of the strong factual basis for the plea demonstrated by the State and Alford's clearly expressed desire to enter it despite his professed belief in his innocence, we hold that the trial judge did not commit constitutional error in accepting it."

50. See, e.g., United States v. Rogers, 289 F. Supp. 726 (1968).

51. For those who prefer somewhat harder data than these speculations, consult Alschuler, The Defense Attorney's Role in Plea Bargaining, 84 YALE L.J. 1179, 1278-1306 (1975).

52. 400 U.S. 25 (1970).

53. Id. at 32 .

54. Id. at 36 .

55. Jd. at 37-38. 
In a footnote, the Court yet again emphasized the "proper caution" announced by federal rule and by state and federal courts that "pleas coupled with claims of innocence should not be accepted unless there is a factual basis for the plea." 56

Quite evidently, the Court is more concerned with the fact of guilt than with the defendant's readiness to admit it. And rightly so. Confession may be good for the soul but truth is good for justice. "Truth," that is, as judges know the term. In Alford, of course, North Carolina graciously provided the most comforting truth-divining procedure aside from a full-scale trial: The facts supporting the plea where adjudicated from live testimony. Thus, strictly reading the decision, it might be taken only as constitutional sanction for a defendant's choice to accept resolution of disputed facts by the sort of minitrial which North Carolina calls a guilty plea. In describing the procedure, ${ }^{57}$ for example, the Court seems to liken Alford's conviction to a verdict:

Although denying the charge against him, he [Alford] nevertheless preferred the dispute between him and the State to be settled by the judge in the context of a guilty plea proceeding rather than a formal trial. Thereupon, with the State's telling evidence and Alford's denial before it, the trial court proceeded to convict and sentence Alford for second-degree murder. . .

It is far from certain, however, that such a restrictive interpretation is necessary to relieve the Court's concern lest the innocent be convicted by their own pleas of guilty. And the questions that Alford leaves unanswered require thoughtful attention: (1) Does the express confession to culpable particulars at the time of the plea satisfy the need for a factual basis in support of the plea and adequately guard against false pleas? If so, should the confession be in any special form? (2) If additional support is required, or in the case where a confession is witheld, what is the meaning of the term "factual basis"? (3) What are the proper means for the establishment of the factual basis for the plea? It is with these questions in mind that we turn once again to the models.

The American Bar Association Standard and the Uniform Rules agree that there must be a "factual basis" for all guilty pleas. ${ }^{58}$ Neither formal text, however, spends a single sentence on the meaning of the term or the proper means of its discovery. Nor is the omission unintentional. The Commentary to the ABA formulation, echoed in the URCP annotation, reports a choice to leave the matter "largely to the discretion of the judge," since "the circumstances of the case will often dictate the kind and amount of inquiry which is necessary. $"$ 5y

\footnotetext{
56. Id. at 38 n. 10 .

57. Id. at 32-33.

58. Standards Relating to Pleas of Gullty, supra note 22, \$1.6; Uniform Rules 444(b)(3).

59. Standards Relating to Pleas of Guilty, supra note 22, \& 1.6 , Comment, quoled in UNiform Rules 444(b)(3), Comment.
} 
There is one curious and unexplained difference between the two formulations. Perhaps there is some significance to it, perhaps not. Rule 444(b)(3) of the Uniform Rules states that the court shall defer acceptance of the plea until it is satisfied there is a factual basis for either the charged or pleaded offense. ABA Standard 1.6 reads: "Notwithstanding the acceptance of a plea of guilty, the court should not enter a judgment upon such plea without making such inquiry as may satisfy it that there is a factual basis for the plea." The ABA Commentary, describing with approval the developing voir dire practice, offers no clue as to why the recommended search for factual bases was inserted between the pleading and the sentence rather than before entry of the plea. While on its face it appears to regard material in the customary pre-sentence report as the appropriate source for the discovery of the facts, the Commentary does not affirm that interpretation. ${ }^{60}$

The Commentary accompanying ABA Standard 1.6 (which, it should be recalled, preceded the Alford decision by about two years) also embellishes the black letter regarding the plea without confession. It notes that: ${ }^{61}$

If the trial judge is otherwise satisfied that there is a factual basis for the plea, it is not required that he call upon the defendant to make an unequivocal confession of guilt. [A somewhat curious statement in view of the timing suggested for the inquiry in the black letter standard, but let it pass.] On the other hand, if the defendant is called upon to make a statement and he denies commission of the offense, then, notwithstanding the existence of other information tending to verify the accuracy of the plea, it would be inappropriate for the judge to enter judgment on the plea.

Further, as to the nolo contendere plea, the Commentary notes that no inquiry into factual basis is necessary.

Thus, reading the provision with its commentary, the ABA holds, in sum, that a guilty plea with an express denial precludes the entry of judgment on it regardless of the strength of independent evidence of guilt, but prior judicial satisfaction that the defendant is indeed guilty obviates the necessity of asking him about it. In any case other than the express denial or a nolo plea, however, the court must undertake some "inquiry" (similar to that noted by the revisers of Federal Rule 11) of the defendant, the government attorneys, or by examining the pre-sentence report to satisfy itself by whatever quantum it deems appropriate of the accuracy of the plea in reflecting the defendant's guilt. While the Uniform Rules quotes a portion of the ABA Commentary, it is difficult to learn from the text how fully or precisely the Commission intended to track the earlier proposal, or how firmly they rejected the intervening decision of the Supreme Court in Alford \%. North Carolina.

The American Law Institute generally agrees that the guilty plea should

60. Standards Relating to Pleas of Guilty, supra note 22, $\$ 1.6$, Comment.

61. Id. 
be to a charge which has some foundation in fact. But happily, their Model Code eschews the exotic term "factual basis" in favor of a more familiar and defined standard. Section 350.4(3) provides that, unless a prior judicial determination was previously made on a preliminary hearing, the court shall not enter judgment on a guilty plea without inquiry to satisfy itself that "reasonable cause" exists. "Reasonable cause" is defined as evidence which would support a guilty verdict and includes consideration of the credibility of witnesses and the "quality" of the evidence. ${ }^{62}$ The Code goes on to state that the court may accept a guilty plea though the defendant does not admit his guilt if the court finds it "reasonable for someone in the defendant's position to plead guilty."63 The Reporter's notes afford further explanation. The court may find reasonable cause, according to the notes, "by examination of witnesses or reading their statements or by a detailed statement of the evidence by the prosecutor." 64 The notes also contradict the ABA's distinction between the mute and denying defendant. Taking account of the Alford decision, and realistically recognizing the ease with which pleading confessions may be forged where necessary, the Reporters simply allow the prudent plea from a defendant notwithstanding his stated or unstated version of the facts.

The National Advisory Commission, rejecting the ALI allowance (and, implicitly the Alford holding along with it)-indeed, differing with the recommendation of its own task force-stipulates that a court may not accept a guilty plea if " $\mathrm{t}] \mathrm{h}$ he defendant continues to assert facts that, if true, establish that he is not guilty of the offense to which he seeks to plead." 65 Since the proposal also requires that each defendant render a "detailed statement" concerning the crime, the case of the mute pleader presumably cannot arise. ${ }^{66}$ The framers, in their commentary, recognize that their position may penalize some innocent defendants who, convicted after trial, suffer the lost benefits of the plea bargain. But they conclude somewhat cryptically, "The Commission believes that this factor is outweighed by the dangers of innocent defendants being convicted and the criminal justice system being disparaged."

The NAC adheres to the ALI standard in requiring all guilty pleas to be supported by sufficient evidence to support a guilty verdict, adding only, again in commentary, that where necessary for a "satisfactory investigation of the facts, the court should require the prosecutor to call its witnesses for sworn testimony." 68

Even availing ourselves fully of the commentaries, it is difficult to sort out

62. Pre-Arraignment Procedure $\$ 330.5(3)$.

63. Id. $\$ 350.4(4)$.

64. Id. $\S 350.4(4)$, Note.

65. NAC Courts RePort $\$ 3.7(9)$.

66. Id.

67. Id. $\S 3.7$, Comment.

68. Id. 
the diverse advice of the several models to find answers to the questions upon which we consulted them. Some selection, synthesis, and supplementation may be in order. Perhaps it would be well to start out with the principle best expressed by the ALI Code: No defendant should called upon to plead except to a well-founded charge. A charge may be defined as well-founded where the credible and admissible evidence is legally sufficient to support a verdict of guilt. Since credibility is a factor, defenses may be considered which bear on the veracity of prosecution witnesses, such as the defense of alibi. However, full opportunity for cross-examination and impeachment is probably inappropriate for a determination of legal sufficiency. Somewhat more troublesome problems are posed by other defenses such as lack of culpability (i.e., lack of, or diminished, criminal intent) and exemptions such as youthfulness. As to these, it would seem that a charge should not be sustained if either can be established by clear and convincing evidence. But where close and difficult questions of fact are raised, resolution would seem more fitting to the trial mode and any evidence from which culpability or liability could be reasonably inferred must be deemed sufficient to warrant the charge.

A question might also arise in some cases concerning the point in time at which the prosecution case need be complete. On that, it is probably best to say simply that the evidence in hand must add up to a sufficient case at the time it is tested. This solution, however, is somewhat controversial, for it means that if the case passed the test at some time prior to the plea (at the preliminary hearing, for example), the legal foundation is not destroyed though the prosecution has lost track of an essential witness by the time the matter comes up for disposition. Similarly, the suggestion tolerates a guilty plea to a case sufficient at the time of plea though the charge was lodged at a time when the case suffered gaps in proof.

For those many jurisdictions providing a forum for testing the sufficiency of all charges before filing the accusatory instrument upon which the plea may be entered, these requirements are not unsettling. The only problems might be two. First, do local criteria for preliminary adjudication comport with those suggested? Do they afford sufficient assurance that a charge may not be lodged solely on the hearsay rendition, for example, of an investigating officer? In this connection, it might be remembered that the quality of proof deemed sufficient to indict in federal courts allows just such reports. Second, where means for challenging the adequacy of the accusation are provided by the law of the jurisdiction, should the failure of the defendant to avail himself of the opportunity be considered a waiver of the issue of sufficiency? Specifically, should a defendant who does not ask for a preliminary hearing or move to dismiss an indictment on the grounds of insufficient underlying evidence be permitted to plead guilty to the indictment without further judicial inquiry into its merits? I would think it no affront to the 
governing principle to deem "regular" and lawful any charge unchallenged by a counseled defendant given adequate opportunity to do so. Just as I do not think a pre-pleading examination of the evidence is necessary as a sort of review of a prior finding of sufficiency, $I$ do not think justice demands that the pleading court assure itself of the bona fides of a charge which the defendant has freely accepted as valid.

This latter comment may serve to identify a tacit point in the preceding discussion. In the transfiguration of "factual basis" into legal sufficiency (or "reasonable cause," as the ALI would have it), the element of accuracy may have been somewhat diminished. ${ }^{69}$ A finding of legal sufficiency is a long way from proof beyond a reasonable doubt (the standard of truth-testing needed for conviction by verdict), and a fair distance from clear and convincing evidence. It does not even require the judge to whom the plea is offered to "satisfy himself" (in the terms of the American Bar Association and Uniform Rules) by a preponderance of the evidence. It is enough if he judges that the evidence is such that a fact finder might lawfully find guilt. This view, however, does no violence to the holding in Alford which only requires a "factual basis" for the plea where the defendant does not accompany his plea with a confession, a case to which we now turn our attention.

Having already agreed with the ALI that a well-founded charge is enough to allow a guilty plea thereon, the defendant's confession at the time of his plea may be regarded simply as one item of evidence upon which a finding of sufficiency may rest. This may mean that for those jurisdictions which require some corroboration of a confession (e.g., by independent proof of the corpus delicti), further inquiry must be made by the judge if no prior determination of sufficiency were made or waived. And if the statement of the pleading defendant admits certain elements (participation, for example) but denies others (force, for example), the judicial inquiry should focus on supporting the elements denied. Where no admissions are tendered by the defendant (or denials or defenses supplied), and no prior adjudication of sufficiency was either made or waived (a rare case in a well-coded jurisdiction), the problems are of greater magnitude.

It is here that adherence to the principle of the well-founded charge threatens collision with constitutional doctrine. For in the view of the Court, and of the National Advisory Commission, and partially in the view of the American Bar Association, when a defendant denies the charge to which he seeks to plead guilty, or declines to admit culpability, special caution is re-

69. "Legal sufficiency," as used generally, means admissible evidence which, if believed beyond a reasonable doubt, establishes every element of the offense. Unlike "reasonable cause" as defined for these purposes by the ALI, legally sufficient evidence does not normally imply credible evidence; only where essential evidence is deemed "incredible as a matter of law," will the case fall below sufficiency. 
quired to prevent conviction of an innocent person. Despite the equanimity of the ALI, such special caution probably demands more than the simple finding of a legally sufficient case. We may protest (as indeed I do) that the theme of the guilty plea is a sensible settlement and not adjudication of true guilt, but the protest is vain in view of the Supreme Court reasoning, even if it could surmount the combined weight of the models. Thus it may be that in this instance the pleading court, alerted by the defendant's stand, must undertake a broader, more searching inquiry de novo, and find facts more persuasive of true guilt than the mere minimum necessary to support the charge. Examining prior minutes and hearing the prosecutor describe the evidence he hopes to adduce can hardly be enough (again, with the deference due the contrary view of the ALI). "For in essence, such inquiry is little more than checking off expected evidence against elements of the crime-a finding of legal sufficiency in another form.

At least as to the disputed aspects of the case, one would think that a process more nearly approaching the Alford mini-trial is required. Without live evidence, it is extremely difficult for the court to resolve issues of credibility between the prosecution witnesses and the defendant. If, as the Court indicates in Alford, the trial judge must, in effect, "find" guilt by resolving factual issues, he must go beyond asking the prosecutor to justify his charging decision, and beyond perceiving evidence in written statements or testimony which contradicts the defendant's averrals. While it probably overruns the mark to declare that in order to "convict" the defendant on his plea, the trial judge must find his guilt beyond a reasonable doubt (as due process requires at trial), ${ }^{1}$ one might choose the "clear and convincing" standard as the most appropriate to the purpose.

Finally, though it be in vain and without the ability to alter mechanical requisites, I cannot leave the topic without observing that, even taken at its strongest meaning and in the special context of its necessary operation, the "factual basis" component of a guilty plea does not truly serve the ends for which it was designed. When all the proof is in and passes judicial muster, the judge's conclusion must be read to mean that the prosecution case against the defendant is strong, and the defendant is wise to plead guilty rather than choose a trial. The conclusion therefore attests to the fact that the waiver has been intelligent, voluntary, and well-counseled. It does not-it cannot-verify the accuracy of the resultant judgment of conviction any more than a jury verdict can be verified or the truthfulness of a confession accompanying a guilty plea can be certified.

70. At least one circuit has apparently taken a different view. In United States v. Gaskins, 485 F.2d 1046 (D.C. Cir. 1973), the court, satisfied with the prosecutor's description of the evidence he expected to adduce at trial, went beyond Alford to find a reversible abuse of discretion in the trial court's refusal to accept the plea of an "equivocating" defendant.

71. In re Winship, 397 U.S. 358 (1970). 


\section{III}

\section{Withdrawal of the Guilty Plea}

More than a few defendants, having registered their submission to judgment, revise their strategy before or shortly after sentence is pronounced. Having confessed or not, the guilty plea now seems a mistake and they seek by motion to withdraw it and cancel the bargain. Perhaps the crushing finality of their previous gesture now seems frightening to them and they try to reopen the case in an irrational urge to forestall judgment. Perhaps cool reappraisal, consultation with a more optimistic lawyer, the appearance of a new witness, or discovery of a recent appellate decision motivates the change in the defendant's mind. The question is to what extent, in what circumstances, on what grounds should the defendant be entitled unilaterally to revoke his carefully supervised plea of guilty?

Permitting free withdrawal, or even putting the state to the burden of showing prejudice in order to make the plea stick, degrades the solemnity of the plea. On the other hand, to deny a motion to withdraw is to press judgment upon a defendant whose predicate plea is no longer voluntary. The makings of a true dilemma are visible. Another occasion for consulting the model makers is at hand.

We notice first that only two of our four guides have thought enough of the problem to address it directly. The National Advisory Commission offers no advice whatever on the subject and the American Law Institute alludes to withdrawal only in passing. The ALI provides that if the trial judge discovers that he must sentence the defendant more severely than contemplated in the plea agreement, he shall so inform the defendant and advise that he will "entertain a motion to withdraw the plea." 72 Not much help.

It is the first of our group of models, the ABA Standards, duly amended to take account of the ALI suggestion, which offers the most comprehensive and carefully structured guidance on the problem. ${ }^{73}$ Standard 2.1 is divided

72. Pre-Arraignment Procedure $\$ 350.6$

73. 2.1 Plea withdrawal.

(a) The court should allow the defendant to withdraw his plea of guilty or nolo contendere whenever the defendant, upon a timely motion for withdrawal, proves that withdrawal is necessary to correct a manifest injustice.

(i) A motion for withdrawal is timely if made with due diligence, considering the nature of the allegations therein, and is not necessarily barred because made subsequent to judgment or sentence.

(ii) Withdrawal is necessary to correct a manifest injustice whenever the defendant proves that:

(1) he was denied the effective assistance of counsel guaranteed to him by constitution, statute, or rule;

(2) the plea was not entered or ratified by the defendant or a person authorized to so act in his behalf;

(3) the plea was involuntary, or was entered without knowledge of the charge or that the sentence actually imposed could be imposed; [or] 
into two parts: withdrawal of right and discretionary withdrawal. The first part provides that the plea may be withdrawn on a timely motion when necessary to correct a "manifest injustice." A timely motion is defined as one made with due diligence measured by the nature of its allegations; the moment of judgment, it is specified, does not necessarily end timeliness. Five forms of "manifest injustice" are described. They relate to whether the bargain was counseled, understood, voluntarily accepted, and honored. None is premised on factual innocence, and the Standard expressly provides that no allegation of innocence is necessary. By omission, it is clear also that mandatory cancellation is not affected by prejudice to the state. The second part allows the court, before sentence, in the absence of substantial prejudicial reliance by the prosecution, to permit withdrawal for "any fair and just reason." Standard 2.2 stipulates that a withdrawn plea is not admissible against the defendant in any subsequent criminal proceeding. ${ }^{74}$ With respect to withdrawing the plea, the Uniform Rules are virtually identical to the ABA Standards, except that the "fair and just reason" clause is posed by the Rules in the imperative voice. ${ }^{75}$ Amplified some, the Standard's proscription against subsequent evidentary use reappears in Uniform Rule 444(f).

In commenting on their provisions, the draftsmen of the ABA Standards point out that a defendant will be hard put to demonstrate, by the requisite clear and convincing evidence, that withdrawal is necessary to correct a manifest injustice if the court to which he pleaded scrupulously followed the standards governing the manner in which a plea should be examined prior to acceptance. Yet the provisions governing withdrawal are both more and less than a simple enforcement mechanism for the principles of acceptance. Failure of adherence, the Commentary notes, does not automatically result in manifest injustice. Where, for example, a judge failed to advise the defendant of the sentence he faced, the defendant would have to show in addition that

(4) he did not receive the charge or sentence concessions contemplated by the plea agreement and the prosecuting attorney failed to seek or not to oppose these concessions as promised in the plea agreement; or

(5) he did not receive the charge or sentence concessions contemplated by the plea agreement concurred in by the court, and he did not affirm his plea after being advised that the court no longer concurred and being called upon to either affirm or withdraw his plea.

(iii) The defendant may move for withdrawal of his plea without alleging that he is innocent of the charge to which the plea has been entered.

(b) In the absence of a showing that withdrawal is necessary to correct a manifest injustice, a defendant may not withdraw his plea of guilty or nolo contendere as a matter of right once the plea has been accepted by the court. Before sentence, the court in its discretion may allow the defendant to withdraw his plea for any fair and just reason unless the prosecution has been substantially prejudiced by reliance upon the defendant's plea.

Standards Relating to Pleas of Guilty, supra note $22, \S 2.1$.

74. This is a rule of long standing. See Kercheval v. United States, 274 U.S. 220 (1927).

75. UNIFORM RULES 444(e). 
he was actually ignorant of it. On the other hand, a defendant might show involuntariness though the court had examined him on the question at the time of the plea.

Basically, the ABA formulation is a good solution to a thorny problem. At least to pragmatists, it comports well with the theory of the guilty plea. And as a good code should, it seems to strike a proper balance between the clear enunciation of guiding tenets and the reservation of space for judgment in their application. It is, moreover, the more praiseworthy for the odd oversight of the august ALI and the silence of the NAC. Fair quarrels with the ABA are, accordingly, few and they sound mostly in terms of additional grounds which might have been better elevated from the discretionary "fair and just reason" group to the mandatory "manifest injustice" category.

For example, suppose it should be discovered that there was some major flaw in the procedures for assuring the accuracy of the plea? Though he need not do so, what if a defendant asserts or reasserts his factual innocence coupled with proof of perjury by an essential prosecution witness who testified at a preliminary proceeding or before the judge taking the plea? Whether by the rubric of the ABA's pleading standards or otherwise, an essential component of the valid guilty plea is foundation in fact. What could be more manifestly unjust, what could more urgently require cancellation of the plea than a demonstrable perversion in the process by which that foundation was laid?

Or suppose the defendant credibly asserts that the prosecutor misrepresented some critical fact to the defendant's counsel or concealed from him material exculpatory evidence during plea negotiations, causing the defendant to miscalculate the strength of the state's case for trial. Unless this claim could be brought within the meaning of "involuntary" (which seems doubtful), the Standards do not term it a manifest injustice. While a defect of this sort impugns less the accuracy of the judgment than the fairness of the bargaining process, voiding the plea on these grounds seems consistent with the theme of the other specified types of fatal faults. It must also be acknowledged that misfeasance by the prosecutor in the negotiation is a more variable factor, and perhaps less compelling than a witness's perjury. But if the fraud is so clear and harmful that even a verdict would have been set aside had the case travelled that route, it would appear to qualify for the mandatory vacation of a guilty plea as well.

One other minor quarrel might be mentioned. For the significant array of claims outside the designation "manifest injustice," the Standards omit a definition which might be useful. The term "fair and just reason" seems clear enough and probably could bear no circumscription, but the notion of "prejudice," or "prejudicial reliance by the prosecution," in this context is somewhat perplexing. What sort of harm to his position, suffered by reason of the defendant's guilty plea, might a prosecutor assert to prevent the withdrawal of the plea, notwithstanding fair and just reasons for cancellation? If 
the prosecutor released an available witness who then disappeared, or if he approved the destruction of necessary physical evidence, could he maintain a claim of prejudice, though his loss was due to foolish and precipitous dissolution of his case? And if the witness evaporated on his own without the prosecutor's action in reliance on the plea, can he claim prejudice by reason of the plea withdrawal?

And what of harms less than wholly destructive of his trial position? Suppose the prosecutor recommended a plea for two codefendants, only to find later that one wishes to withdraw and stand trial alone. Can he argue that his position on trial is more tenuous, particularly since the pleaded defendant might take the stand and "take the weight" alone in an effort to spring his erstwhile partner? And apart from real or feared injuries to trial strength, can the prosecutor assert additional labor and expense as prejudice? For example, if the trial assistant, thoroughly prepared by extensive investigation to try the case, left the office after the plea, major efforts might be required to educate a substitute. If a vital police witness retired and moved to Florida, it could break the prosecutor's meagre budget to bring him back and lodge him during a protracted trial.

Clearly, prejudice spans a wide gradient. As used here to nail the defendant to his plea despite good reasons to release $\mathrm{him}$ from the bargain, the term "prejudice" could have used some elaboration to reveal the nature of the harm the framers of the Standard had in mind.

\section{Conclusion}

The guilty plea is a legal event of some complexity, well deserving the attention recently accorded it. Concerning at least three of its aspects-the process of its negotiation, the truth of it, and the proper circumstances of its voidance-courts and model makers evince considerable disagreement. Yet as a result of their efforts, our appreciation of the problems is enriched and perhaps the development of a practical and coherent doctrine is begun.

At the start, it would seem that the negotiated settlement of a criminal case (over the dissent of the National Advisory Commission) must be firmly accepted as a respectable conclusion of prosecution. Both the shame of compromise and the righteous demand for full retribution must fade. Instead, attention should be focused, without apology, on assuring legal regularity in the process. Too, the quasi-religious view of the plea as a blind and penitent confession must yield to the pragmatic ideal of an informed and voluntary choice of mutually advantageous terms between adversaries. Judgment by plea, properly supervised, is no inferior brand of justice to judgment by verdict. But carefully structured standards and procedures must invigorate public faith that the courtroom is still an honorable forum.

As important as the oral litany accompanying the entry of a plea is the 
manner in which it is arrived at by the parties. Not all terms or conditions are properly subject to negotiation. Not all means of persuasion are appropriate to bargaining. Thus, standards should enunciate the rights or prerogatives which a defendant may not be called upon to sacrifice as well as the circumstances deemed improper as conditions precedent to the plea. Too, the obligations of the parties to full disclosure at the pre-pleading conferences require articulation. Without total revision of the adversary mode or needless peril to the case should the plea talks fail, enough must be divulged-at least by the government-to inform the choice of the defendant. And a defendant should not be denied the benevolent participation of a judge in the bargaining process, nor the helpful disclosure of formulated judicial disposition, by exaggerated and misplaced concern over judicial detachment and the defendant's freedom of choice.

In addition to providing assurances of a free and intelligent choice in the pleading decision, some relation should be established between the guilty plea and the factual occurrence to which it speaks. In the spectrum between presumed regularity in the charging instrument and trying the plea to the point that a jury would convict lies the proper mode for allaying fears of convicting the innocent by voluntary plea. At least in the ordinary case in which the defendant supplies a culpable account with his plea, a legally sufficient case behind the charge, or the waiver of its demonstration should suffice through it falls far short of the quality of proof otherwise necessary to satisfy a fact finder of criminal liability. If the defendant's refusal to confess, denial, or defense signals greater danger of erroneous judgment, the pleading court should probably search the evidence and weigh credibility by more careful methods than recorded or reported proof allow.

Finally, a court should allow the unilateral cancellation of the plea, regardless of prejudice or the time at which a diligent motion is brought, in any case in which some fundamental ingredient of a proper plea may be shown to have been ignored, misperceived, or perverted. A number of these have been identified by the ABA Standards, but the list is a bit short. The ABA, with fine restraint, also allows for nullification of the plea on less momentous faults and fouls, but places even the fair and just grounds with in the discretionary realm and cuts them off absolutely with the pronouncement of sentence. However, the ABA has stipulated that even the fairest and most just of the reasons in this secondary category cannot undo the plea over a tenable assertion of "prejudice" by the prosecutor. A term of such breadth in this somewhat unusual setting could have profited by the merest hint of definition. But here-as in so many other places-our devoted guides leave us sighing. Is it not wonderful how stubbornly the law resists completion though four great expeditions separately set upon the task? 